\title{
Why Urban Citizens in Developing Countries Use Traditional Medicines: The Case of Suriname
}

\author{
Tinde van Andel ${ }^{1}$ and Luísa G. Carvalheiro ${ }^{1,2}$ \\ ${ }^{1}$ Naturalis Biodiversity Center, P.O. Box 9514, 2300 RA Leiden, The Netherlands \\ ${ }^{2}$ School of Biology, University of Leeds, Leeds LS2 9JT, UK \\ Correspondence should be addressed to Tinde van Andel; tinde.vanandel@naturalis.nl
}

Received 28 January 2013; Accepted 17 March 2013

Academic Editor: Andrea Pieroni

Copyright ( 2013 T. van Andel and L. G. Carvalheiro. This is an open access article distributed under the Creative Commons Attribution License, which permits unrestricted use, distribution, and reproduction in any medium, provided the original work is properly cited.

\begin{abstract}
The use of traditional medicines (TMs) among urban populations in developing countries and factors underlying people's decision to use TMs are poorly documented. We interviewed 270 adults in Paramaribo, Suriname, using a stratified random household sample, semistructured questionnaires, and multivariate analysis. Respondents mentioned 144 medicinal plant species, most frequently Gossypium barbadense, Phyllanthus amarus, and Quassia amara. 66\% had used TMs in the previous year, especially people who suffered from cold, fever, hypertension, headache, uterus, and urinary tract problems. At least $22 \%$ combined herbs with prescription medicine. The strongest explanatory variables were health status, (transfer of) plant knowledge, and health status combined with plant knowledge. Other predictive variables included religion, marital status, attitude of medical personnel, religious opinion on TMs, and number of children per household. Age, gender, nationality, rural background, education, employment, income, insurance, and opinion of government or doctors had no influence. People's main motivation to use TMs was their familiarity with herbs. Given the frequent use of self-collected, home-prepared herbal medicine and the fact that illness and traditional knowledge predict plant use rather than poverty or a limited access to modern health care, the potential risks and benefits of TMs should be put prominently on the national public health agenda.
\end{abstract}

\section{Introduction}

The use of complementary and alternative medicine (CAM) has become increasingly popular in the last few decades. A 1990 survey in the United States revealed that one-third of the American adults used "unconventional therapies" [1], while natural products for health purposes were used by $19 \%$ of the population in 2002 [2]. Almost half of the Southern Australians used nonmedically prescribed alternative medicine in 2000 [3]. Reports from Western Europe suggest that $20 \%$ (The Netherlands) to $49 \%$ (France) of the population has used CAM at least once [4]. CAM types reported in these surveys included homeopathy, acupuncture, herbal medicine, dietary supplements, manual therapy, and specific prayers [2-4]. Demographic and personal factors underlying people's decision to use CAM included higher education [1, $3,5]$, declining health status [5], higher income $[1,3]$, female, and employed $[3,6]$. People's own motivations for using
CAM were to prevent illness [3], curiosity, and the idea that combining it with conventional treatment would help [2]. A holistic or a spiritual health view and the belief that herbs are natural (and thus safe) also seem associated with CAM use [7]. Migrants in Europe and USA generally continue their traditional practices, including the use of traditional medicines [8-10]. Surinamese migrants in The Netherlands, interviewed in 2007, were more likely to use TMs when they believed in the existence of spirits, had been ill in the past year, and frequently visited their motherland. Their main personal motivation to use TMs was that they were part of their culture [11].

Citizens in developed countries may prefer CAM over or in combination with conventional treatment, but people in developing countries seem to have fewer options to choose from [12]. According to the World Health Organization [13], the percentage of the population in developing countries that depends on traditional medicine (TM) for their primary 
health care ranges from $40 \%$ (Colombia) to $90 \%$ (Ethiopia). How these figures were calculated is not revealed in the WHO statistics, nor do we know the share of herbal medicine within these TM percentages. Most figures seem to refer to rural communities that have a limited access to conventional medicine and are surrounded by environments in which herbs are easily accessible $[12,14]$. However, an increasing number of people in developing countries now live in urban areas. Few of these large cities are able to provide their rapidly growing populations with the appropriate health care, which often results in increased levels of urban poverty and ill health [15]. While we are gaining insight in the use of CAM in developed countries, the use of herbal medicine or other forms of TM among urban populations in developing countries is poorly documented [12]. When 1072 citizens of Belo Horizonte (Brazil) were asked for their motivations for medicinal plant use [14], 15\% said that herbs were more effective than conventional therapies, while $6 \%$ associated them with lower side effects. More than $60 \%$ of the patients from a clinic in Trujillo (Peru) said they used medicinal herbs; $35 \%$ used them more often than pharmaceuticals [16]. Of the 388 randomly selected healthy adults from Lagos (Nigeria), 67\% had used herbal medicine in the past six months [17]. Researchers explained the high prevalence of herbal medicine use by massive rural-to-urban migration [14], influence of cultural and social surroundings [17], and the belief that natural products pose no risk $[16,17]$. In the only study that analyzed the predictive factors for herbal medicine use in a developing country [18], 73\% of the 372 randomly selected Jamaicans had used herbs in the past year. While age, employment, education, gender, health insurance, and religion predicted plant use, rural or urban residence had no influence. With the increasing popularity of CAM in developed countries and the high prevalence of TM use in developing ones, it is important for biomedical practitioners to understand their patients' motivation to use herbs or other forms of TM, the potential benefits of medicinal plants, and possible adverse effects or interactions with prescription medicine $[2,18,19]$.

The current paper aims to describe use patterns and uncover the predictive variables for the use of traditional medicines among citizens of Paramaribo, Suriname. This former Dutch colony in northern South America became independent in 1975 and almost half of its inhabitants live in the capital Paramaribo (pop. 242,946 in 2004). In the period $2000-2006,27 \%$ of the population was earning less than US\$ 2 per day [20], there were 45 physicians per 100,000 people, and infant mortality was 30 per 1,000 live births [21]. Lacking sufficient means to provide for their basic needs, $59 \%$ of the urban and $63 \%$ of the rural population were considered to be poor [22]. Traditional medicines are popular in Suriname, both for physical ailments and for spiritual healing therapies. Medicinal plants as well as other forms of traditional medicine are locally known as "oso dresi" (home remedies). At least 400 different plant species are used, of which more than half are sold on Paramaribo's market $[23,24]$. No national policies, laws, or regulations on TM exist in the country [25]. To reveal who uses home remedies in Paramaribo, what they take, and why they do this, we need to answer the following questions: (1) which types of traditional medicine are used by urban Surinamers and for what health conditions? (2) Which demographic, socioeconomic psychological factors predict the use of TMs? (3) What are people's personal motivations to use TMs? We expect that similar factors are associated with the use of TMs in Suriname as in Jamaica [18] and the use of CAM in developing countries [1-6]. Although there may be no formal policies on TM in Suriname, the opinion of politicians, religious leaders, and conventional health care practitioners may still influence people's decision regarding its use. Outcomes of this study can help to develop a national policy for TM in Suriname, but also contribute to general models that account for the use of traditional medicines among urban citizens in the developing world.

\section{Materials and Methods}

2.1. Sample Selection. Fieldwork was conducted in June and July 2006. Since we had no access to recent birth and death registers from Paramaribo and many inhabitants are not registered, we could not draw a random sample of all citizens. Therefore, we chose to approach participants directly in their home surroundings, using a stratified random sampling method [26, 27]. On the road map of Paramaribo [28], we selected the 94 populated quadrants and randomly placed 276 dots with a marker: three dots per quadrant in the average neighborhood, four dots in heavily populated ones (visible as many small streets), two dots in sparsely populated areas, and one dot in squares that were occupied for more than $50 \%$ by vegetation or water.

Interviews were carried out by the first author, six students, and two staff members of the Anton de Kom University in Paramaribo. Each dot on the map was visited by one or two interviewers in the late afternoon, when people generally return from work. The interviewer(s) approached the house closest to the dot on the map for a face-to-face interview with one household member of 18 years or older. When people refused to participate (mostly because of lack of time) or when there was nobody present, we selected the nearest house where someone agreed to be interviewed. Prior to the interview, participants were handed out an information sheet in Dutch that contained the aims of the study, its institutional setting, and contact information of the first author. After obtaining oral informed consent, the interview was held in Dutch, Sranantongo, Hindustani, or Javanese, according to the language preferred by the participants. All interviewees remained anonymous and received US\$3.60 for their contribution. After exclusion of six of the 276 participants (younger than 18 years, lost or halfway terminated interviews, person was not part of the household), 270 interviews were included in our analysis. Permission to conduct this study was obtained from the Ministry of Public Health in Paramaribo (letter no. 1328).

2.2. Questionnaires. To find out which factors significantly influenced people's choice for traditional medicines, a pretested, semistructured questionnaire was designed (see 
Supplementary Material available online at http://dx.doi.org/ $10.1155 / 2013 / 687197)$, based on a multivariate model of human health care seeking behavior [29]. The first part contained questions related to demographic, socioeconomic, and psychosocial factors (e.g., religion, beliefs, and opinion). Participants were then asked whether they knew and used plants or other home remedies for health promotion, disease prevention, or cure. The interview continued with questions related to the occurrence of an illness the past 12 months and actions taken to overcome this ailment. Participants were asked for their opinion on the quality of both conventional health care and traditional healers in Suriname, as well as the attitude of these providers towards their patients and the standpoints of the government, church, and health care personnel towards TMs. Finally, we asked participants for their own motivation for using traditional medicines and how they obtained the raw material. The interviews were part of a larger ethnobotanical research project on Surinamese medicinal plants, carried out from January to July 2006 $[23,24]$. Vernacular plant names mentioned during the interviews were connected to voucher specimens collected earlier. In a few cases, plants were collected in the respondent's garden. Duplicates of all plant vouchers were deposited at the National Herbaria of Suriname (BBS) and The Netherlands (L). Botanical research and plant export permits were obtained from the Nature Conservation Division of the Suriname Forest Service (no. 08208).

2.3. Statistical Analysis. To assess whether the use of traditional medicines was explained by people's social and cultural background, we tested the effect of each of the explanatory variables listed in Tables 1 and 2. The dependent variable, a dichotomous measure (yes or no), was defined as the use within the previous 12 months of any crude or processed plant or animal product for health promotion, disease prevention, or cure. As many of the variables correlated, we used generalized linear models with family binomial to examine which explanatory variables had predictive value for the use of TMs. All explanatory variables and all two-way interactions between them were evaluated in a multivariate logistic regression model selection to assess whether the use of TMs could be explained by a combination of independent variables. To select the most parsimonious model (the model that maximizes the amount of variability explained per number of variables used), we used forward and backward stepwise selection and chose the model with the lowest AIC (Akaike Information Criterion) and BIC (Bayesian Information Criterion). We then ran pairwise tests for all factorial explanatory variables that were selected in the best model. The Pearson $\gamma^{2}$ test was applied to examine correlations between variables. To evaluate if the occurrence of an illness affected the number of plants used for health promotion, disease prevention, or cure, we used the nonparametric Mann-Whitney $U$ test after a Kolmogorov-Smirnov test indicated that the response variable was not normally distributed. In all analyses, $P<$ 0.05 was considered statistically significant. Analyses were conducted using the statistical software packages IBM SPSS 19.0 and R 2.15.1 [30], using the package lme4 [31].

\section{Results}

3.1. Characteristics of the Response Group. The study population consisted of 89 males and 181 females, mostly born in Suriname, with a median age of 42 (Table 1). AfroSurinamers and Hindustani formed the most prominent ethnic groups. More than half of the respondents were living with a partner; the mean number of children per household was 1.8 . The majority (79\%) had followed at least a few years of high school, but $44 \%$ was unemployed, although these figures include students, retired people, and housewives. Nearly three-quarters had a low income. Most were Christians (66\%), followed by Hindu (14\%). Only six persons listed the traditional Afro-Surinamese winti belief as their official religion, but more than half of the interviewees said they believed in the existence of winti or other spiritual beings. Almost all respondents (94\%) believed that herbs had the power to heal people; less than half thought they also possessed magic power.

3.2. Use of Traditional Medicine. A total of 231 respondents (86\%) reported to have used traditional medicines at some point in their life, while 177 (66\%) had used at least one product during the past 12 months (Table 2). Only $11 \%$ stated explicitly that they did not use home remedies. More people used herbs for health promotion than for disease prevention or to cure an illness. The majority (72\%) had received knowledge on herbs, mostly from their family. Books were not an important source of information; $28 \%$ of the respondents said they had never been taught about traditional medicines. People who used herbs mostly collected them in their own garden or neighborhood; $28 \%$ obtained them from family or friends, while $24 \%$ bought them on the market. Few received herbs from traditional healers. When asked for their personal motives to use home remedies, $40 \%$ said they were accustomed to use herbs; they "grew up with them" (Table 2). Other arguments were that herbs were more effective, safe and caused fewer side effects, or conventional treatment did not work. Only $12 \%$ mentioned that herbs were more accessible than prescription medicine, but just three persons said they were cheaper. Many persons gave several motives.

3.3. Illnesses. Of the 174 persons who had been ill the past 12 months, 33\% had a chronic disease (Table 2). Cold and related issues such as influenza and cough were the most common ailments. Of those who had been ill, 73\% had used traditional medicines. Medicinal plant use was highest (70 to $100 \%$ ) among people who suffered from cold, fever, hypertension, headache, uterus problems, injuries, and urinary tract problems (including sexually transmitted diseases). Those with arthritis, hernia, and skin problems less often used TM (33-35\%). Most people who had been ill consulted a doctor; $44 \%$ took herbal medicine as cure. Patients generally combined several actions. One-third of the respondents knew a traditional healer; 11 persons said they were one, but only $3 \%$ had visited one in the previous year. Of those who had been sick, $22 \%$ combined herbs with prescription medicine. Another 24 patients took herbs and went to see a doctor, but 
TABLE 1: Demographic, socioeconomic, and psychological characteristics of the 270 respondents and their use of traditional medicines during the previous 12 months.

\begin{tabular}{|c|c|c|c|}
\hline Variables and classes & $N$ & Percentage (\%) & Use of TMs in the last 12 months (\%) \\
\hline \multicolumn{4}{|l|}{ Sex } \\
\hline Male & 89 & 33 & $58(65)$ \\
\hline Female & 181 & 67 & $119(66)$ \\
\hline Age (median no. of years) & 42 & & \\
\hline Children in the household (mean \pm st. dev.) & $1.8 \pm 1.8$ & & \\
\hline Lived in interior (mean nr. years \pm st. dev.) & $4.71 \pm 9.0$ & & \\
\hline \multicolumn{4}{|l|}{ Country of birth } \\
\hline Suriname & 245 & 91 & $162(66)$ \\
\hline The Netherlands & 7 & 3 & $6(86)$ \\
\hline \multicolumn{4}{|l|}{ Nationality } \\
\hline Surinamese & 245 & 91 & $161(66)$ \\
\hline Dutch & 14 & 5 & $11(79)$ \\
\hline \multicolumn{4}{|l|}{ Marital status } \\
\hline Married/cohabiting & 149 & 55 & $91(61)$ \\
\hline Single (incl. widow, divorced) & 107 & 40 & $73(68)$ \\
\hline LAT (partner lives elsewhere) & 14 & 5 & $13(93)$ \\
\hline \multicolumn{4}{|l|}{ Ethnic group } \\
\hline Afro-Surinamese & 112 & 41 & $86(77)$ \\
\hline Hindustani & 63 & 23 & $32(51)$ \\
\hline Mixed & 54 & 20 & $40(74)$ \\
\hline Javanese & 20 & 7 & $6(30)$ \\
\hline Other (White, Chinese, and Brazilian) & 21 & 8 & $13(62)$ \\
\hline \multicolumn{4}{|l|}{ Speaks Dutch } \\
\hline Well & 207 & 77 & $138(67)$ \\
\hline Moderately & 48 & 18 & $31(65)$ \\
\hline Badly & 15 & 6 & $8(53)$ \\
\hline \multicolumn{4}{|l|}{ Educational level } \\
\hline Low (sprimary school) & 36 & 13 & $21(58)$ \\
\hline Moderate (high school, Com. College) & 213 & 79 & $143(67)$ \\
\hline High (college or university) & 21 & 8 & $13(62)$ \\
\hline \multicolumn{4}{|l|}{ Employment level } \\
\hline None & 120 & 44 & $76(63)$ \\
\hline Part time (1-4 days/week) & 33 & 12 & $23(70)$ \\
\hline Full time (5-7 days/week) & 117 & 43 & $78(67)$ \\
\hline \multicolumn{4}{|l|}{ Monthly income } \\
\hline Low $(<\$ 550)$ & 192 & 71 & $123(64)$ \\
\hline Moderate $(\$ 550-910)$ & 39 & 14 & $24(62)$ \\
\hline High $(>\$ 911)$ & 26 & 10 & $22(85)$ \\
\hline \multicolumn{4}{|l|}{ Religion } \\
\hline None & 17 & 6 & $9(53)$ \\
\hline Christian-Catholic & 85 & 32 & $60(71)$ \\
\hline Christian-Protestant & 93 & 34 & $69(74)$ \\
\hline Hindu & 39 & 14 & $20(51)$ \\
\hline Muslim & 27 & 10 & $12(44)$ \\
\hline Winti & 6 & 2 & $6(100)$ \\
\hline \multicolumn{4}{|l|}{ Belief in winti/spirits } \\
\hline Yes & 139 & 51 & $101(73)$ \\
\hline No & 131 & 49 & $76(58)$ \\
\hline
\end{tabular}


TABle 1: Continued.

\begin{tabular}{lccc}
\hline Variables and classes & $N$ & Percentage (\%) & Use of TMs in the last 12 months (\%) \\
\hline Belief healing power plants & & & $172(67)$ \\
$\quad$ Yes & 255 & 94 & $5(33)$ \\
$\quad$ No & 15 & 6 & $91(73)$ \\
Belief magic power plants & 125 & 46 & $86(59)$ \\
$\quad$ Yes & 145 & 54 & $77(65)$ \\
No & & & $55(61)$ \\
Insurance & 119 & 44 & $42(76)$ \\
$\quad$ Total coverage & 89 & 33 & 20 \\
$\quad$ Partial coverage & 53 & & \\
$\quad$ No insurance & & & \\
\hline
\end{tabular}

did not mention the use of synthetic drugs. Nine persons visited a doctor and a traditional healer for the same illness, but neither referred to herb or drug use. Although not explicitly mentioned, persons from the latter two groups probably also used herbs in conjunction with prescription medicine. Of the people who had not been ill, $48 \%$ used medicinal plants to promote their health, $22 \%$ to prevent disease, and $6 \%$ to cure an ailment they did not report.

3.4. Plant Species Known and Used. All medicinal products are listed with their local and scientific names, parts used, and citation scores in the supplementary Appendix 2. At least 144 plant species were mentioned during the interviews, belonging to 66 families, with the Solanaceae as most diverse one (11 species), followed by Fabaceae (8 spp.), Asteraceae (7), and Euphorbiaceae (7). Eighteen herbal products could not be connected to a scientific name: two were native plants with undocumented vernacular names; 11 were mixtures of two or more species. Of the 144 plant species, 118 were used in the past 12 months. At least 18 plant species, several Asian mixtures, and all chemical substances were imported. Ten people said they had used herbal medicine but did not know the name of the particular plant. Bitter tonics (used by 17 respondents) consisted of a mixture of several bittertasting plants listed separately in Appendix 2. Apart from honey (cited 10 times), animal products like deer horn or snake fat were mentioned only sporadically. A few synthetic substances (e.g., camphor, magnesium sulfate, and Reckitt blue laundry whitener) were also considered as traditional medicines by our respondents, but they were mostly added to plant mixtures.

A red cotton cultivar (Gossypium barbadense) was by far the best known and most frequently used plant (Table 3). A tea from its leaves was drunk to regulate menstruation and treat uterus problems. Phyllanthus amarus and Quassia amara were two common ingredients of bitter tonics, drunk to promote one's health, treat menstruation problems, and ease the symptoms of diabetes. Since people did not always know the ingredients of their ready-made bitter tonics, these species were probably more frequently used than those listed here. Surinamese herbal medicine is not always that traditional: the Pacific fruit Morinda citrifolia was only promoted since the 1990 s as a medicinal product, but now figures in the top five of most cited species. Processed herbal medicine imported from The Netherlands (e.g., echinaforce) was also mentioned as a "home remedy." While $4 \%$ of the respondents did not know any medicinal plant, $61 \%$ provided information on more than three species (Table 2). People who had been ill in the previous year used significantly more plant species for disease prevention and cure than those who did not report an illness (Table 4), but the number of species used for health promotion did not differ between the two groups. More than half of our respondents used plants for health promotion, regardless whether they had been ill or not (Table 2), while ca. 35\% of the respondents used plants for disease prevention and/or cure. More plants were used to cure an illness (72\% of all species) and for health promotion (61\%) than for disease prevention (48\%), but many of the most popular species were used in all three categories. Onefifth of the respondents occasionally sent herbal medicine to friends or relatives in The Netherlands; $4 \%$ did this on a regular basis.

3.5. Acceptance of Herbal Medicine by Local Institutions. Our data suggest that TM is fairly well accepted by the Surinamese medical staff: $31 \%$ of our respondents said their doctor accepted both traditional healers and herbal medicine; 21 persons reported that some physicians suggested their patients to visit a traditional healer or use herbs (Table 2). Another $21 \%$ said that the opinion on TM varied among doctors: some accepted herbs but rejected traditional healers. According to $27 \%$, their health care providers rejected both herbs and healers. Although $62 \%$ of the respondents were positive about the quality of conventional health care in Suriname, more than half were critical about the attitude of the medicinal personnel towards patients: 18 people said that they were only nice to rich people; 13 had experienced hospital staff that cursed at their patients. A 56-year-old female teacher reported: "they treat you like a dog, only if you have money and they know what kind of insurance you have" (they are willing to help you).

Our respondents generally found that traditional healers treated their patients with more respect than conventional health care providers. A 54-year-old housewife explained: "traditional healers have to treat their patients respectfully in order to get their money." 
TABLE 2: Knowledge, opinion, and practice regarding TMs among the 270 respondents.

\begin{tabular}{|c|c|c|}
\hline Variables and classes & $N(\%)$ & $\begin{array}{l}\text { Use of TMs } \\
\text { in the last } 12 \\
\text { months (\%) }\end{array}$ \\
\hline Uses medicinal herbs (sometimes) ${ }^{\S, *}$ & $231(86)$ & \\
\hline Used herbs the last 12 months & $177(66)$ & \\
\hline Used herbs for health promotion ${ }^{\S}$ & $147(54)$ & \\
\hline Used herbs for disease prevention ${ }^{\S}$ & $94(34)$ & \\
\hline Used herbs as cure for illness ${ }^{\S}$ & $98(36)$ & \\
\hline \multicolumn{3}{|l|}{ Knowledge of herbs* } \\
\hline None & $12(4.4)$ & $2(8.3)$ \\
\hline 1-3 plant species & $94(35)$ & $48(51)$ \\
\hline$>3$ plant species & $164(61)$ & $127(77)$ \\
\hline \multicolumn{3}{|l|}{ Received information on herbs } \\
\hline None & $76(28)$ & $34(45)$ \\
\hline From family & $150(56)$ & $116(77)$ \\
\hline From friends, colleagues, neighbors & $32(12)$ & $20(63)$ \\
\hline From books & $3(1)$ & $2(67)$ \\
\hline \multicolumn{3}{|l|}{ Illness last 12 months } \\
\hline Yes & $174(64)$ & $127(73)$ \\
\hline No & $96(36)$ & $50(52)$ \\
\hline \multicolumn{3}{|l|}{ Duration of illness $(n=174)^{\S}$} \\
\hline Acute & $118(68)$ & $86(73)$ \\
\hline Chronic & $58(33)$ & $43(74)$ \\
\hline \multicolumn{3}{|l|}{ Type of illness $(n=174)^{\S, * *}$} \\
\hline Cold, influenza, cough & $76(44)$ & $54(71)$ \\
\hline Fever & $20(11)$ & $14(70)$ \\
\hline Hypertension & $17(10)$ & $14(82)$ \\
\hline $\begin{array}{l}\text { Arthritis, rheuma, joint pains, } \\
\text { hernia }\end{array}$ & $17(10)$ & $6(35)$ \\
\hline Headache, migraine & $15(9)$ & $11(73)$ \\
\hline Stomach/intestinal problems & $16(9)$ & $10(63)$ \\
\hline Diabetes & $14(8)$ & $9(64)$ \\
\hline Skin problems, wounds, rash & $9(5)$ & $3(33)$ \\
\hline Menstruation, uterus problems & $6(3)$ & $6(100)$ \\
\hline Mental and spiritual health & $6(3)$ & $4(67)$ \\
\hline Injuries, fractures & $5(3)$ & $4(80)$ \\
\hline Urinary tract problems (incl. STDs) & $5(3)$ & $4(80)$ \\
\hline Other & $35(20)$ & $24(69)$ \\
\hline \multicolumn{3}{|l|}{ Action patient $(n=174)^{\S, * *}$} \\
\hline Doctor & $116(81)$ & $75(65)$ \\
\hline Herbal medicine & $76(44)$ & $76(44)$ \\
\hline Prescription medicine & $52(30)$ & $38(73)$ \\
\hline Herbs + prescription medicine & $38(22)$ & $38(100)$ \\
\hline Religious activities & $18(7)$ & $12(67)$ \\
\hline Traditional healer & $5(3)$ & $5(100)$ \\
\hline Other (diet, rest, nothing) & $27(16)$ & $11(41)$ \\
\hline
\end{tabular}

TABLE 2: Continued.

\begin{tabular}{|c|c|c|}
\hline Variables and classes & $N(\%)$ & $\begin{array}{l}\text { Use of TMs } \\
\text { in the last } 12 \\
\text { months (\%) }\end{array}$ \\
\hline \multicolumn{3}{|l|}{ Sends plants to The Netherlands } \\
\hline Never & $199(74)$ & $121(61)$ \\
\hline Sometimes & $59(22)$ & $44(75)$ \\
\hline Regularly & $12(4)$ & $12(100)$ \\
\hline \multicolumn{3}{|l|}{ Sources of herbs $(n=231)^{\S, * *}$} \\
\hline Own garden or surroundings & $117(51)$ & $90(77)$ \\
\hline Family, friends & $65(28)$ & $58(89)$ \\
\hline Market, shop & $55(24)$ & $44(80)$ \\
\hline Interior of Suriname & $30(13)$ & $26(87)$ \\
\hline Traditional healer & $9(4)$ & $6(67)$ \\
\hline \multicolumn{3}{|l|}{$\begin{array}{l}\text { Motives for medicinal plant use } \\
(n=213)^{\S, * *}\end{array}$} \\
\hline Accustomed to using herbs & $92(40)$ & $76(83)$ \\
\hline Plants work better than pills & $71(31)$ & $54(76)$ \\
\hline Herbs are safe & $51(22)$ & $39(76)$ \\
\hline Less side effects & $52(23)$ & $42(81)$ \\
\hline $\begin{array}{l}\text { Doctor or pills cannot cure my } \\
\text { illness }\end{array}$ & $33(14)$ & $17(52)$ \\
\hline Other (e.g., cheaper, easy access) & $27(12)$ & $20(74)$ \\
\hline \multicolumn{3}{|l|}{ Knows traditional healer } \\
\hline No & $178(66)$ & $111(62)$ \\
\hline Yes & $92(34)$ & $66(72)$ \\
\hline \multicolumn{3}{|l|}{ Quality of traditional healers } \\
\hline Good & $125(46)$ & $86(69)$ \\
\hline Depends on healer and illness & $108(40)$ & $73(68)$ \\
\hline Bad & $18(7)$ & $9(50)$ \\
\hline \multicolumn{3}{|l|}{$\begin{array}{l}\text { Attitude of traditional healer towards } \\
\text { patients }\end{array}$} \\
\hline Good & $139(51)$ & $92(66)$ \\
\hline Depends on person & $66(24)$ & $50(76)$ \\
\hline $\mathrm{Bad}$ & $2(1)$ & $8(61)$ \\
\hline \multicolumn{3}{|l|}{ Quality of conventional health care } \\
\hline Good & $167(62)$ & $108(65)$ \\
\hline Depends on doctor and illness & $88(33)$ & $64(73)$ \\
\hline Bad & $9(3)$ & $3(33)$ \\
\hline \multicolumn{3}{|l|}{$\begin{array}{l}\text { Attitude of health personnel towards } \\
\text { patients }\end{array}$} \\
\hline Good & $93(34)$ & $68(73)$ \\
\hline Depends on doctor or nurse & $144(53)$ & $89(62)$ \\
\hline $\mathrm{Bad}$ & $30(11)$ & $18(60)$ \\
\hline \multicolumn{3}{|l|}{$\begin{array}{l}\text { Opinion of doctors on traditional } \\
\text { medicine }\end{array}$} \\
\hline Both healers and herbs accepted & $83(31)$ & $60(72)$ \\
\hline None accepted & $73(27)$ & $43(59)$ \\
\hline Depends on doctor & $31(11)$ & $23(74)$ \\
\hline Herbs accepted, (some) healers not & $27(10)$ & $21(78)$ \\
\hline Does not know doctor's opinion & $56(21)$ & $30(54)$ \\
\hline
\end{tabular}


TABLE 2: Continued.

\begin{tabular}{lcc}
\hline Variables and classes & $N(\%)$ & $\begin{array}{r}\text { Use of TMs } \\
\text { in the last } 12 \\
\text { months }(\%)\end{array}$ \\
\hline $\begin{array}{l}\text { Opinion of religion on traditional } \\
\text { medicine }\end{array}$ & $95(35)$ & $69(73)$ \\
$\quad$ Both healers and herbs accepted & $70(26)$ & $46(66)$ \\
Herbs accepted, (some) healers not & $66(24)$ & $40(61)$ \\
Does not know & $35(13)$ & $19(54)$ \\
None accepted & $11(4)$ & $3(75)$ \\
$\begin{array}{l}\text { Depends on type of healer and } \\
\text { priest }\end{array}$ & & \\
$\begin{array}{l}\text { Opinion of government on traditional } \\
\text { medicine }\end{array}$ & $108(40)$ & $76(70)$ \\
Both healers and herbs accepted & $31(11)$ & $21(68)$ \\
Forbidden by law & $3(1)$ & $3(100)$ \\
$\begin{array}{l}\text { Depends on healer and politician } \\
\text { Herbs accepted, (some) healers not }\end{array}$ & $7(3)$ & $7(6)$ \\
Is not aware of govt. opinion & $116(43)$ & $70(60)$ \\
\hline
\end{tabular}

*As most traditional medicines consist of medicinal plants, the term "herbs" is used here.

${ }^{* *}$ More answers were possible so sum of percentages may be over $100 \%$.

${ }^{\S}$ Variable not included in the multivariate analysis.

Our results reflect the lack of an official policy on TM in Suriname: $43 \%$ of the respondents were not aware of any government opinion on the use of herbs. Several people thought that TM was accepted since politicians themselves went to traditional healers or practiced winti rituals, while $11 \%$ thought that both herbs and traditional healers were prohibited by law. The largest group of respondents (35\%) felt that their religion accepted both herbs and healers; $30 \%$ said that this depended on the type of healers (winti priests were mostly not accepted) and the type of herbal medicine (ritual uses were often rejected). Just 13\% said their religion opposed both herbs and healers. A 54-year-old Afro-Surinamese man, who used six different plant species to cure his chronic joint pains, told us that although his church rejected herbal medicine, his culture allowed him to use it.

3.6. Statistical Analysis. Many of the explanatory variables were correlated. For example, ethnicity was correlated with religion $\left(\gamma^{2}=200.9, P<0.01\right)$, the belief in winti $\left(\gamma^{2}=\right.$ 16.3, $P<0.05)$, knowing a traditional healer $\left(\gamma^{2}=7.9\right.$, $P<0.05)$, and being taught on traditional medicines $\left(\gamma^{2}=\right.$ 23.3, $P<0.01)$. Independent factors that explained the variability of the data in the multivariate analysis were listed in two models: a more conservative model based on BIC and a less conservative one based on AIC (Table 5). The strongest predictors for TM use were retained in the most conservative model: the occurrence on an illness, the number of medicinal plant species known, and having received information on traditional medicine.

We also found interaction between illness and plant knowledge. People who had been ill in the past 12 months

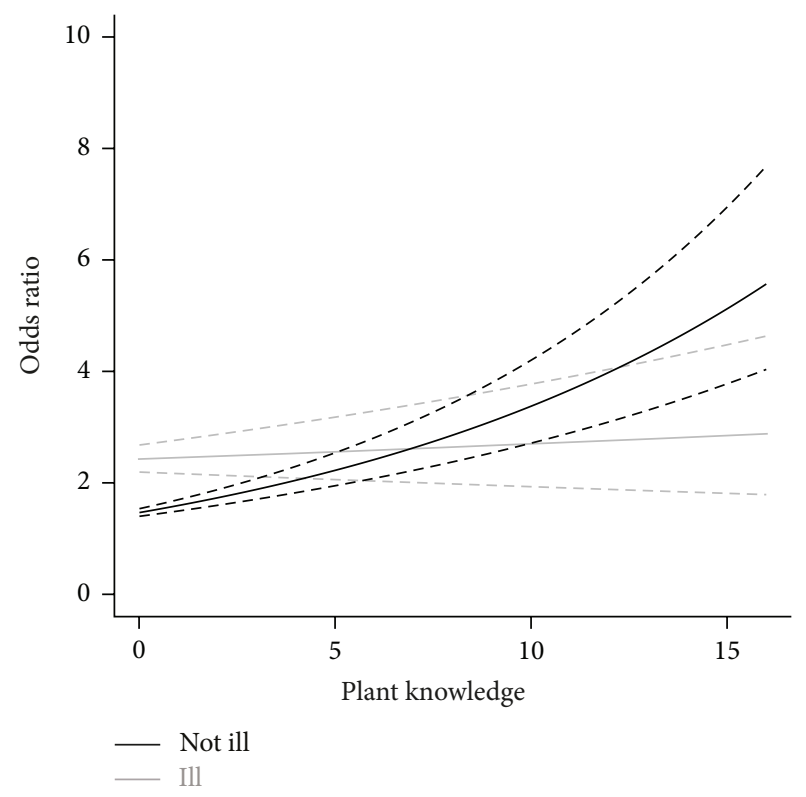

FIGURE 1: Relation between plant knowledge (no. of species used) and the use of traditional medicines (odds ratio) among people who did and did not suffer from an illness during the past 12 months. Odds ratio values were obtained from the most parsimonious model (lowest AIC and BIC), as the exponential of the estimates provided by generalized linear models with family binomial.

used herbs more often than those who had not; independently of whether the disease was chronic or acute. Persons who had not suffered from any illness were more likely to use herbs (for health promotion and disease prevention), particularly when their plant knowledge was higher. For those who had been ill, this interaction was not significant (Figure 1). Other variables that influenced the use of TMs were selected in the least conservative model (AIC model, Table 5). The results of this model suggest that, apart from the variables mentioned earlier, the use of herbs was linked to being Christian, single, positive about the attitude of medical staff towards patients, living in a household with many children, and feeling that one's religion accepted both herbs and traditional healers. Respondents who listed winti as their official religion all used herbal medicine, but this group was too small to make differences significant. Age, gender, nationality, country of birth, the number of years spent in rural areas, education, employment, income, health insurance, and the opinion of medical staff or the government towards TM did not have a significant influence on people's decision to use traditional medicine.

\section{Discussion}

4.1. Self Medication with Home-Prepared Herbs. Apart from the occurrence of an illness, knowledge of the healing properties of plants and their preparation methods and the transfer of such knowledge appeared to be major factors that influenced the use of traditional medicines among urban Surinamers. Even though $34 \%$ of our study group 
TABLE 3: Most frequently mentioned and used medicinal plant species by our study group.

\begin{tabular}{|c|c|c|c|c|c|c|}
\hline $\begin{array}{l}\text { Species } \\
\text { (voucher number) }\end{array}$ & Family & $\begin{array}{c}\text { Local name } \\
\text { (Sranantongo) }\end{array}$ & Plant part & Uses & $\begin{array}{c}\text { Times cited } \\
(\%)\end{array}$ & $\begin{array}{l}\text { Used } \\
(\%)\end{array}$ \\
\hline $\begin{array}{l}\text { Gossypium barbadense } \\
\text { (TVA 4921) }\end{array}$ & Malvaceae & $\begin{array}{l}\text { Redi katoen, red } \\
\text { cotton }\end{array}$ & Leaves & $\begin{array}{l}\text { Urinary tract problems, regulate } \\
\text { menstruation, cleanse uterus, } \\
\text { hypertension }\end{array}$ & $58(21)$ & $37(14)$ \\
\hline $\begin{array}{l}\text { Phyllanthus amarus } \\
\text { (TVA 4870) }\end{array}$ & Phyllanthaceae & Fini bita & Entire plant & $\begin{array}{l}\text { Cleanse uterus, regulate menstruation, } \\
\text { diabetes, hypertension }\end{array}$ & $48(18)$ & $34(13)$ \\
\hline $\begin{array}{l}\text { Quassia amara } \\
\text { (TVA 4829) }\end{array}$ & Simaroubaceae & Kwasibita & Wood & Fever, aphrodisiac, malaria, bitter tonic & $48(18)$ & $32(12)$ \\
\hline $\begin{array}{l}\text { Azadirachta indica } \\
\text { (TVA 5539) }\end{array}$ & Meliaceae & Neem & Leaves & $\begin{array}{l}\text { Hypertension, diabetes, skin problems, } \\
\text { malaria }\end{array}$ & $39(14)$ & $19(7)$ \\
\hline $\begin{array}{l}\text { Morinda citrifolia } \\
\text { (TVA 4761) }\end{array}$ & Rubiaceae & Noni & Fruit & Cancer, diabetes, HIV, skin problems & $36(13)$ & $19(7)$ \\
\hline $\begin{array}{l}\text { Cymbopogon citratus } \\
\text { (TVA 4839) }\end{array}$ & Poaceae & $\begin{array}{l}\text { Citroengras, } \\
\text { lemongrass }\end{array}$ & Leaves & Cold, fever, cough, flu & $35(13)$ & $20(7)$ \\
\hline $\begin{array}{l}\text { Momordica charantia } \\
\text { (TVA 5494) }\end{array}$ & Cucurbitaceae & Sopropo (wild) & Entire plant & $\begin{array}{l}\text { Diabetes, hypertension, cleanse uterus, } \\
\text { stomach problems }\end{array}$ & $31(11)$ & $16(6)$ \\
\hline Allium sativum & Alliaceae & Knoflook, garlic & Bulb & $\begin{array}{l}\text { Hypertension, diabetes, fever, spiritual } \\
\text { problems }\end{array}$ & $29(11)$ & $19(7)$ \\
\hline- & - & Bita (bitter tonics) & $\begin{array}{l}\text { Various } \\
\text { species }\end{array}$ & Cleanse uterus, regulate menstruation & $29(11)$ & $17(6)$ \\
\hline $\begin{array}{l}\text { Peperomia pellucida } \\
\text { (TVA 4851) }\end{array}$ & Piperaceae & Konsaka wiwiri & Entire plant & Eye infection, fever, asthma, nausea & $20(7)$ & $12(4)$ \\
\hline Cocos nucifera & Arecaceae & $\begin{array}{l}\text { Kokosnoot, } \\
\text { coconut }\end{array}$ & $\begin{array}{l}\text { Fruitshell, } \\
\text { coconut milk, } \\
\text { oil } \\
\end{array}$ & $\begin{array}{l}\text { Hypertension, skin problems, hair oil, } \\
\text { cold, diarrhea }\end{array}$ & $17(6)$ & $10(4)$ \\
\hline $\begin{array}{l}\text { Eugenia uniflora } \\
\text { (TVA 5330) }\end{array}$ & Myrtaceae & Monkimonki kersi & Leaves & $\begin{array}{l}\text { Cold, headache, sore throat, anaemia, } \\
\text { fever }\end{array}$ & $17(6)$ & $8(3)$ \\
\hline $\begin{array}{l}\text { Annona muricata } \\
\text { (TVA 5150) }\end{array}$ & Annonaceae & Zuurzak & Leaves & $\begin{array}{l}\text { Sleeplessness, depression, anxiety, } \\
\text { heart problems }\end{array}$ & $16(6)$ & $9(3)$ \\
\hline $\begin{array}{l}\text { Scoparia dulcis } \\
\text { (TVA 4966) }\end{array}$ & Scrophulariaceae & Sisibi wiwiri & Entire plant & $\begin{array}{l}\text { Sore throat, fever, toothache, } \\
\text { hypertension, laxative, hepatitis }\end{array}$ & $16(6)$ & $9(3)$ \\
\hline Aloe vera & Asphodelaceae & Aloe vera & Leaves & $\begin{array}{l}\text { Wounds, skin infections, rash, hair } \\
\text { problems, malaria, diabetes }\end{array}$ & $13(5)$ & $8(3)$ \\
\hline $\begin{array}{l}\text { Psidium guajava } \\
\text { (TVA 5129) }\end{array}$ & Myrtaceae & Goyave & Fruit, leaves & $\begin{array}{l}\text { Diarrhea, dysentery, fever, cold, } \\
\text { stomach pains, cleanse uterus }\end{array}$ & $13(5)$ & $6(2)$ \\
\hline Saccharum officinarum & Poaceae & $\begin{array}{l}\text { Suikerriet, ingi } \\
\text { tjen, melasse }\end{array}$ & $\begin{array}{l}\text { Stem, leaves, } \\
\text { syrup, juice }\end{array}$ & $\begin{array}{l}\text { Cold, cough, flu, asthma, skin } \\
\text { infection, spiritual problems }\end{array}$ & $12(4)$ & $11(4)$ \\
\hline $\begin{array}{l}\text { Citrus aurantifolia } \\
\text { (TVA 5132) }\end{array}$ & Rutaceae & Lemmetje & Fruit & $\begin{array}{l}\text { Cold, cough, flu, asthma, dysentery, } \\
\text { skin infections }\end{array}$ & $12(4)$ & $10(4)$ \\
\hline - & - & Bitter vegetables & $\begin{array}{l}\text { Various } \\
\text { species }\end{array}$ & $\begin{array}{l}\text { Health promotion, anaemia, diabetes, } \\
\text { migraine, stress }\end{array}$ & $12(4)$ & $7(3)$ \\
\hline- & & Herbal bath & $\begin{array}{l}\text { Various } \\
\text { species }\end{array}$ & Spiritual problems, good luck & $12(4)$ & $7(3)$ \\
\hline
\end{tabular}

TABLE 4: Effect of the occurrence of an illness in the previous 12 months on the number of plant species used for health promotion, disease prevention, and cure. Mean numbers of plant species ( \pm standard error) used are provided. Data on number of plants used were not normally distributed, so $P$ values were derived form a Mann-Whitney $U$ test.

\begin{tabular}{lcccc}
\hline Health status & $N(\%)$ & $\begin{array}{c}\text { Plants used for health promotion } \\
\text { (mean no. spp. } \pm \text { std. error) }\end{array}$ & $\begin{array}{c}\text { Plants used for disease prevention } \\
\text { (mean no. spp. } \pm \text { std. error) }\end{array}$ & $\begin{array}{c}\text { Plants used for cure } \\
\text { (mean no. spp. } \pm \text { std. error) }\end{array}$ \\
\hline Ill last 12 months & $174(64)$ & $1.10 \pm 1.3$ & $0.71 \pm 1.1$ & $1.05 \pm 1.3$ \\
Not ill & $96(36)$ & $0.81 \pm 1.2$ & $0.47 \pm 1.2$ & $0.12 \pm 0.5$ \\
Total & $\mathbf{2 7 0}(\mathbf{1 0 0 )}$ & $\mathbf{1 . 0} \pm \mathbf{1 . 3}$ & $\mathbf{0 . 6 2} \pm \mathbf{1 . 2}$ & $\mathbf{0 . 7 2} \pm \mathbf{1 . 1}$ \\
$P$ value & - & 0.44 & 0.006 & $<0.0001$ \\
\hline
\end{tabular}


TABLE 5: Variables that best explained the variability in use of traditional medicines in the last 12 months. Information on the most parsimonious model obtained when using AIC or BIC during model selection is presented. Negative values for the deviance to the reference level imply a lower probability of TM use than the reference group (deviance $=0$ ).

\begin{tabular}{|c|c|c|c|c|c|c|c|}
\hline \multirow{3}{*}{ Variables } & \multirow{2}{*}{$n(\%)^{\S}$} & \multirow{2}{*}{$\begin{array}{c}\text { Slope of } \\
\text { covariates }\end{array}$} & \multirow{2}{*}{$\begin{array}{l}\text { Deviance to } \\
\text { reference }\end{array}$} & \multirow{3}{*}{$\begin{array}{l}\text { Std. } \\
\text { error }\end{array}$} & \multicolumn{3}{|c|}{ Pairwise comparison with reference level } \\
\hline & & & & & $T$ value & $P$ value & \\
\hline & & \multicolumn{5}{|c|}{ Best model based on AIC } & \\
\hline \multicolumn{8}{|l|}{ Religion } \\
\hline Christian (reference level) & $178(66)$ & & 0 & - & - & - & \\
\hline Winti & $6(2)$ & & -0.1676 & 0.1883 & -0.9 & 0.3742 & \\
\hline Hindu & $39(14)$ & & -0.2734 & 0.0776 & -3.5 & 0.0005 & $* * *$ \\
\hline Muslim and other & $47(17)$ & & -0.2180 & 0.0704 & -3.1 & 0.0022 & ** \\
\hline Number of children in household ${ }^{\S \S}$ & & 0.0273 & & 0.0140 & 20. & 0.0522 & . \\
\hline Plant knowledge (number of spp.) ${ }^{\S \S}$ & & 0.0108 & & 0.0160 & 0.7 & 0.5020 & \\
\hline \multicolumn{8}{|l|}{ Illness last 12 months } \\
\hline Yes (reference level) & $174(64)$ & & 0 & - & - & - & \\
\hline None & $96(36)$ & & -0.5032 & 0.1101 & -4.6 & $7.53 E-06$ & $* * *$ \\
\hline \multicolumn{8}{|l|}{ Marital status } \\
\hline Single or LAT (reference level) & & & 0 & - & - & - & \\
\hline Married/cohabiting & & & -0.1173 & 0.0530 & -2.2 & 0.0279 & $*$ \\
\hline \multicolumn{8}{|l|}{ Received information on herbs } \\
\hline $\begin{array}{l}\text { From family, friends, and so on } \\
\text { (reference level) }\end{array}$ & $194(72)$ & & 0 & - & - & - & \\
\hline None & $76(28)$ & & -0.1946 & 0.0591 & -3.3 & 0.0011 & $* *$ \\
\hline \multicolumn{8}{|l|}{ Attitude medical staff towards patients } \\
\hline Good (reference level) & $94(35)$ & & 0 & - & - & - & \\
\hline Does not know & $3(1)$ & & 0.0531 & 0.2466 & 0.2 & 0.8298 & \\
\hline Has experienced bad attitude & $173(64)$ & & -0.1355 & 0.0550 & -2.5 & 0.0143 & $*$ \\
\hline \multicolumn{8}{|l|}{$\begin{array}{l}\text { Opinion of religion on traditional } \\
\text { medicine }\end{array}$} \\
\hline Positive (reference level) & $95(35)$ & & 0 & - & - & - & \\
\hline Critical (depends on priest/type of TM) & $74(27)$ & & -0.1994 & 0.0691 & -2.9 & 0.0042 & $* *$ \\
\hline Does not know & $66(24)$ & & -0.1590 & 0.0715 & -2.2 & 0.0271 & $*$ \\
\hline Negative & $35(13)$ & & -0.2110 & 0.0852 & -2.5 & 0.0139 & $* *$ \\
\hline \multicolumn{8}{|l|}{ Illness $*$ plant knowledge } \\
\hline Yes (reference level) & $174(64)$ & & 0 & - & - & - & \\
\hline No & $96(36)$ & & 0.0727 & 0.0235 & 3.1 & 0.0022 & $* *$ \\
\hline \multicolumn{8}{|c|}{ Best model based on BIC } \\
\hline \multicolumn{8}{|l|}{ Received information on herbs } \\
\hline From family, friends, and so on & $194(72)$ & & 0 & & & & \\
\hline None & $76(28)$ & & -1.0551 & 0.3135 & -3.4 & 0.0008 & $* * *$ \\
\hline \multicolumn{8}{|l|}{ Illness last 12 months } \\
\hline Yes & $174(64)$ & & 0 & & & & \\
\hline None & $96(36)$ & & -2.7597 & 0.7834 & -3.5 & 0.0004 & $* * *$ \\
\hline Plant knowledge (number of spp.) ) $^{\S \S}$ & & 0.1102 & & 0.0941 & 1.2 & 0.2415 & \\
\hline \multicolumn{8}{|l|}{ Illness last 12 months $*$ plant knowledge } \\
\hline Yes & $174(64)$ & & 0 & & & & \\
\hline None & $96(36)$ & & 0.4598 & 0.1870 & 2.5 & 0.0139 & $*$ \\
\hline
\end{tabular}

${ }^{\S}$ Because of rounding, percentages do not always total 100.

${ }^{\$ \$}$ Continuous variable.

${ }^{*}$ Level of significance: .: almost significant; ${ }^{*} P<0.05 ;{ }^{* *} P<0.01 ;{ }^{* * *} P<0.001$.

$P$ values $<0.05$ are considered significant. 
knew a traditional healer, few people consulted one for treatment or to buy herbs. Together with the long list of plant species mentioned during the interviews, these outcomes indicate that most people practice self-medication. Popular medicinal plants like red cotton (Gossypium barbadense), noni (Morinda citrifolia), and neem (Azadirachta indica) were not frequently sold at the Paramaribo market in 2006 [24]. They are commonly grown in city gardens and therefore do not have much commercial value, just like the weed Phyllanthus amarus that can be collected for free. The bitter wood of Quassia amara, however, needs to be brought from the interior. Its popularity among urban Surinamers was reflected in a third place on the list of botanicals sold in greatest volume on the city's herbal market [24]. People's main motivation to use TMs was their familiarity with herbs. Remarks like "I grew up with them," "herbal medicine is my belief," and "if tablets don't work, I do it my own way" further confirm the outcomes of our multivariate analysis. Although it seems rather obvious that individual knowledge of plants also suggests their use, Reyes-García et al. [32] prove that these two variables do not necessarily correlate. In societies that have undergone rapid socioeconomic changes, people become more integrated into the market economy and adopt (synthetic) substitutes for plants. This creates a gap between people's ethnobotanical knowledge and their actual use of plants. Our study indicates that in Paramaribo, this is not yet the case.

In contrast to the situation in Jamaica [18], USA and Australia $[1,3,5,6]$, age, employment, income, education, gender, and health insurance did not predict herbal medicine use in Paramaribo, so we reject our hypothesis. Our data further suggest that a clear policy on TM among politicians, religious leaders, and medical personnel has the potential to influence people's health care seeking behavior. Due to the lack of uniform guidelines and contrasting opinions and practices among policy makers in Suriname, people tend to make their own decision. Our results may indicate $66 \%$ of the urban Surinamers regularly use of traditional medicine; this does not mean that they depend on herbs for their primary health care. We did not find any indication that poverty or rural-to-urban migration was related to the use of TMs. Only three respondents mentioned that herbs were cheaper than prescription medicine. Respondents with a low income more often had an insurance that covered all their health costs than people from higher income groups $\left(\gamma^{2}=33.1, P<0.01\right)$, and they used herbal medicine less often, although differences were not significant $\left(\gamma^{2}=4.7, P=0.97\right)$.

4.2. Comparison with Other Studies. The high prevalence of the use of traditional medicine for colds, headache, and intestinal problems in Paramaribo was also observed in Jamaica [18, 19] and Peru [16]. Musculoskeletal conditions and chronic pains were less often treated with herbs in Suriname, but scored high on CAM use in USA $[2,5]$ and herb use in Jamaica [18, 19]. Lifestyle diseases like diabetes and hypertension figured highly on our lists of selfreported ailments and most popular medicinal treatments. Diabetes patients often used bitter vegetables and tonics to ease their symptoms. Research on some of these species (e.g., Phyllanthus amarus and Momordica charantia) has confirmed their ability to lower blood glucose levels [33, 34]. The frequent use of bitter plants to prevent diabetes was also reported among urban citizens in Nigeria [17], Jamaica [18], and among Ghanaian [35] and Surinamese migrants [11] in The Netherlands. Hypertension was often treated with herbal medicine in Suriname and Jamaica [19], but not with CAM in USA, as this condition was effectively managed with pharmaceutical drugs [2].

Familiarity with herbs was also the most important reason to use TMs among Surinamese migrants in The Netherlands [11]. These findings are consistent with earlier arguments that herbal medicine is a deeply rooted cultural preference $[8,16]$. The Afro-Surinamese winti religion, based on spirit possession, ancestor rituals, and herbal baths, still plays a key role in the mental health of Surinamers [36]. Christians in Paramaribo were more likely to believe in winti than other religious groups $\left(\gamma^{2}=15.778, P=0.015\right)$. Plants employed for spiritual purposes and cultural-bound health issues (e.g., health promotion by means of bitter tonics or regular uterus cleansing) were popular among our respondents, Surinamese migrants [11], and figured prominently on the Paramaribo market [24]. Evidence for the association between holistic or spiritual beliefs and CAM use was also found in several studies in Europe, USA and Canada [5, 7, 11], and among Rastafarians (with regards to herb use) in Jamaica [18]. Apart from being familiar with herbs, urban Surinamers also used them because they were more effective, had fewer side effects than prescription medicine, and were safe because of their natural origin. Similar arguments were brought forward by herbal medicine users in Brazil [14], Peru [16], and Jamaica [19], and CAM users in UK [7], The Netherlands [11], and USA [5].

4.3. Strengths and Weaknesses. Strengths of this study are its multidisciplinary approach (combining plant use and public health) and the fact that it is the first multivariate analysis of herbal medicine use among urban citizens in a developing country. Weaknesses include a possible bias towards women, unemployed, and elderly people, who are likely to spend more time at home than others. As we depended on people's willingness to participate, our sample could not be strictly random. Still, door-to-door surveys like ours have long been the standard method to obtain data on public health issues [27]. In developing countries, where few people have private landline phones and reliable birth and death registers are often unavailable, this method still seems the most practical $[17,37]$. Our results are not representative of the country in general. Outside of the capital, health care facilities are much more limited and poverty rates are higher [22], so rural people rely more on TMs for their primary health care than their urban compatriots. The lack of studies that statistically analyze predictive factors for the use of TMs in developing countries makes the comparison of our results with others difficult. 
4.4. Implications for Health Policy Makers. While CAM users in developed countries generally buy processed natural products in stores [2,3], Surinamers mostly prepare their own herbal medicine from self-collected plants or crude material bought on the market. The existence of large medicinal plant markets in urban centers in South America [14, 36, 38], Africa [39-41], Asia [42, 43], the Caribbean [44, 45], and the Middle East [46] suggests that this might be the case in many developing countries. Apparently, even when biomedical health care becomes physically more available, this does not imply that urban citizens will make exclusive use of this system, leaving health care based on traditional plant knowledge behind [47]. Researchers have raised concern about $\mathrm{TM} / \mathrm{CAM}$ use in conjunction with conventional medicine $[2,6,18,19]$. In developing countries, these risks are probably much higher, as people generally combine synthetic medicine with home-made concentrated plant extracts instead of the much more diluted homeopathic products, multivitamins, prayers, and manual therapies used in industrialized countries.

Our data suggest that two-thirds of the urban Surinamers regularly use TMs, a percentage comparable to Peru (60\%) [16] and Nigeria (67\%) [17], but somewhat lower than Jamaica (73\%) [18]. At least $22 \%$ of our respondents combined herb use with prescription medicine for the same illness. This emphasizes the need for studies on the safety and efficacy of frequently used Surinamese herbs. Patients who use herbs while their doctor rejects TMs (59\% in our study) probably do not share this information with him. Doctors should ask about their patient's use of herbs whenever they obtain a medical history and be alert for contraindications and signs of toxicity based on potential drug-herb interactions. Examples for some of the most popular herbs are the smooth muscle contraction activity of Gossypium barbadense [48] and the reproductive toxicity of Quassia amara [49]. Moreover, several species listed in Appendix 2 are poisonous, like Ricinus communis, Spigelia anthelmia, Manihot esculenta (bitter cassava root), and Catharanthus roseus. These plants can cause poisoning even when they are not used in combination with prescription medicine [50].

Traditional medicine typically considers the whole person and the person's cultural beliefs and values in the healing process $[10,47]$. In order to improve people's health condition, it is thus essential to investigate their cultural concepts of health and illness and their health care-seeking behavior. Ethnobotanists have an important role to play in medical education to raise awareness about cultural traditions that include self-treatment with medicinal plants [51]. Future research should focus on ways to improve the communication between doctors and their patients to minimize the risks of combining herbal medicine with conventional treatment, but also to encourage practitioners to negotiate treatment that is acceptable to both clinician and patient [51]. How can herbal medicine be included in health promotion and disease prevention programs?

The outcome of our study that illness and (the transfer of) traditional knowledge are the reasons why urban citizens in Suriname use TMs, rather than poverty or a limited access to modern health care, might be more universal than previously thought. The continued use of medicinal plants in urban areas, where biomedical health care is available to most citizens, has not only been observed in cities in developing countries [14, 16-18], but also among international migrant communities in USA and Europe $[8,9,11,46,51]$. The general idea that traditional knowledge will disappear when people enter the market society [32] is challenged by the popularity of self-medication with medicinal plant use in large urban areas [51]. Research on the potential risks and benefits of traditional medicines should therefore be put prominently on the global public health agenda.

\section{Conclusions}

Two-thirds of the urban Surinamers had used herbal medicine in the past 12 months. The use was highest among those who suffered from cold, fever, hypertension, headache, uterus, and urinary tract problems. In stead of age, gender, nationality, rural background, education, employment, income, insurance, and doctor's or government opinions, plant use was predicted by health status, (the transfer of) plant knowledge, and health status combined with plant knowledge. Other predictive variables included religion, marital status, attitude of medical personnel, religious opinion on TMs, and number of children per household. People's main motivation to use TMs was their familiarity with herbs. Given the frequent use of self-collected, home-prepared herbal medicine and the fact that illness and traditional knowledge predict the use of TMs rather than poverty or a limited access to modern health care, the potential risks and benefits of TMs should be put prominently on the national public health agenda of Suriname. The popularity of self-medication with herbal medicine in urban areas in developing countries and among migrants in Europe and USA suggests that the predictive variables for the use of TMs presented in our study might be more universal than just Suriname.

\section{Conflict of Interests}

The authors have no conflict of interests in this subject.

\section{Authors' Contribution}

T. R. van Andel designed the study, did the fieldwork, analyzed the data, and drafted the paper. L. G. Carvalheiro assisted with the statistical analysis and critically reviewed the paper. Both authors reviewed the final version of the paper.

\section{Acknowledgments}

The authors thank Anjani Ramdjanamsingh, Steven Hofwijks, Regina Burnet, Rayan Madhar, Muriël Djaspan, Angela Grant, Maya Doebar, and Irene Kedoe for their assistance with the interviews in Paramaribo. This study was funded by The Netherlands Organization for Scientific Research (NWO), Grants no. ALW1PJ/04052 and ALW-Vidi no. 864.09.007. 


\section{References}

[1] D. M. Eisenberg, R. C. Kessler, C. Foster, F. E. Norlock, D. R. Calkins, and T. L. Delbanco, "Unconventional medicine in the United States-prevalence, costs, and patterns of use," The New England Journal of Medicine, vol. 328, no. 4, pp. 246-252, 1993.

[2] P. M. Barnes, E. Powell-Griner, K. McFann, and R. L. Nahin, "Complementary and alternative medicine use among adults: United States, 2002," Advance data, no. 343, pp. 1-19, 2004.

[3] A. H. MacLennan, D. H. Wilson, and A. W. Taylor, "The escalating cost and prevalence of alternative medicine," Preventive Medicine, vol. 35, no. 2, pp. 166-173, 2002.

[4] P. Fisher and A. Ward, "Complementary medicine in Europe," British Medical Journal, vol. 309, no. 6947, pp. 107-111, 1994.

[5] J. A. Astin, "Why patients use alternative medicine: results of a national study," Journal of the American Medical Association, vol. 279, no. 19, pp. 1548-1553, 1998.

[6] A. H. MacLennan, D. H. Wilson, and A. W. Taylor, "Prevalence and cost of alternative medicine in Australia," Lancet, vol. 347, no. 9001, pp. 569-573, 1996.

[7] F. L. Bishop, L. Yardley, and G. T. Lewith, "A systematic review of beliefs involved in the use of complementary and alternative medicine," Journal of Health Psychology, vol. 12, no. 6, pp. 851867, 2007.

[8] A. Pieroni and I. Vandebroek, Travelling Cultures and Plants: The Ethnobiology and Ethnopharmacy of Migrations, Berghahn, New York, NY, USA, 2007.

[9] M. J. Balick, F. Kronenberg, A. L. Ososki et al., "Medicinal plants used by Latino healers for women's health conditions in New York City," Economic Botany, vol. 54, no. 3, pp. 344-357, 2000.

[10] P. Muniz de Medeiros, G. Taboada Soldati, N. Leal Alencar et al., "The use of medicinal plants by migrant people: adaptation, maintenance, and replacement," Evidence-Based Complementary and Alternative Medicine, vol. 2012, Article ID 807452, 11 pages, 2012.

[11] T. van Andel and P. Westers, "Why Surinamese migrants in the Netherlands continue to use medicinal herbs from their home country," Journal of Ethnopharmacology, vol. 127, no. 3, pp. 694701, 2010.

[12] G. Bodeker and F. Kronenberg, "A public health agenda for traditional, complementary, and alternative medicine," American Journal of Public Health, vol. 92, no. 10, pp. 1582-1591, 2002.

[13] World Health Organization, Traditional Medicine Strategy 2002-2005, WHO, Rome, Italy, 2002.

[14] M. G. Lins Brandão, F. A. Acúrcio, R. L. Melo Montemor, and L. D. Paes Marlière, "Complementary/alternative medicine in Latin America: use of herbal remedies among a Brazilian metropolitan area population," Journal of Complementary and Integrative Medicine, vol. 3, no. 1, article 5, pp. 1-8, 2006.

[15] J. C. Fotso and C. Mukiira, "Perceived quality of and access to care among poor urban women in Kenya and their utilization of delivery care: harnessing the potential of private clinics?" Health Policy and Planning, vol. 27, no. 6, pp. 505-515, 2012.

[16] R. W. Bussmann, D. Sharon, and A. Lopez, "Blending traditional and Western medicine: medicinal plant use among patients at Clinica Anticona in El Porvenir, Peru," Ethnobotany Research and Applications, vol. 5, pp. 185-199, 2007.

[17] I. A. Oreagba, K. A. Oshikoya, and M. Amachree, "Herbal medicine use among urban residents in Lagos, Nigeria," $B M C$ Complementary and Alternative Medicine, vol. 11, pp. 117-125, 2011.
[18] D. Picking, N. Younger, S. Mitchell, and R. Delgoda, "The prevalence of herbal medicine home use and concomitant use with pharmaceutical medicines in Jamaica," Journal of Ethnopharmacology, vol. 137, no. 1, pp. 305-311, 2011.

[19] R. Delgoda, N. Younger, C. Barrett, J. Braithwaite, and D. Davis, "The prevalence of herbs use in conjunction with conventional medicines in Jamaica," Complementary Therapies in Medicine, vol. 18, no. 1, pp. 13-20, 2010.

[20] United Nations Human Development Report Office, "Human development indices," 2008, http://hdr.undp.org/en/media/ HDI_2008_EN_Tables.pdf.

[21] Central Intelligence Agency, "The world factbook: Suriname," Washington, DC, USA, 2012, https://www.cia.gov/library/publications/the-world-factbook/geos/ns.html.

[22] Algemeen Bureau voor de Statistiek, Suriname: Millenium Development Goals Baseline Report, ABS, Paramaribo, Suriname, 2004.

[23] T. R. van Andel and S. Ruysschaert, Medicinale en Rituele Planten van Suriname, KIT Publishers, Amsterdam, The Netherlands, 2011.

[24] T. Van Andel, J. Behari-Ramdas, R. Havinga, and S. Groenendijk, "The medicinal plant trade in Suriname," Ethnobotany Research and Applications, vol. 5, pp. 351-372, 2007.

[25] World Health Organization, NAtional Policy on Traditional Medicine and Regulation of Herbal Medicines: Report of a WHO Global Survey, WHO, Rome, Italy, 2005.

[26] M. N. Alexiades, Collecting Ethnobotanical Data: Selected Guidelines for Ethnobotanical Research, The New York Botanical Garden Press, New York, NY, USA, 1996.

[27] A. W. Taylor, D. H. Wilson, and M. Wakefield, "Differences in health estimates using telephone and door-to-door survey methods-a hypothetical exercise," Australian and New Zealand Journal of Public Health, vol. 22, no. 2, pp. 223-226, 1998.

[28] Afaka International, Road Map of Paramaribo, Afaka International, Paramaribo, Suriname, 2004.

[29] L. J. Slikkerveer, "A multivariate model of biocultural conservation of medicinal, aromatic and cosmetic (MAC) plants in Indonesia," Ethnobotany Research \& Applications, vol. 3, pp. 127138, 2005.

[30] R Core Team, R: A Language and Environment for Statistical Computing, R Foundation for Statistical Computing, Vienna, Austria, 2012.

[31] D. Bates, M. Maechler, and B. Bolker, Lme4: Linear MixedEffects Models Using S4 Classes. R Package Version 0. 999999-0, R Foundation for Statistical Computing, Vienna, Austria, 2012.

[32] V. Reyes-García, V. Vadez, T. Huanca, W. Leonard, and D. Wilkie, "Knowledge and consumption of wild plants: a comparative study in two Tsimane'villages in the Bolivian Amazon," Ethnobotany Research \& Applications, vol. 3, pp. 201-207, 2005.

[33] J. R. Patel, P. Tripathi, V. Sharma, N. S. Chauhan, and V. K. Dixit, "Phyllanthus amarus: ethnomedicinal uses, phytochemistry and pharmacology: a review," Journal of Ethnopharmacology, vol. 138, no. 2, pp. 286-313, 2011.

[34] B. A. Leatherdale, R. K. Panesar, G. Singh et al., "Improvement in glucose tolerance due to Momordica charantia (karela)," British Medical Journal, vol. 282, no. 6279, pp. 1823-1824, 1981.

[35] B. Boogmans, Ethnobotanical survey of West-African vegetable food in the Netherlands [BSc thesis], Leiden University, Leiden, The Netherlands, 2012.

[36] T. R. van Andel, S. Ruysschaert, K. Vande Putte, and S. Groenendijk, "What makes a plant magical: symbolism and sacred 
herbs in Afro-Surinamese winti rituals," in African Ethnobotany in the Americas, R. Voeks and J. Rashford, Eds., pp. 247-284, Springer, New York, NY, USA, 2012.

[37] O. H. Del Brutto, R. Santibáñez, L. Idrovo et al., "Epilepsy and neurocysticercosis in Atahualpa: a door-to-door survey in rural coastal Ecuador," Epilepsia, vol. 46, no. 4, pp. 583-587, 2005.

[38] R. W. Bussmann and D. Sharon, "Markets, healers, vendors, collectors: the sustainability of medicinal plant use in northern Peru," Mountain Research and Development, vol. 29, no. 2, pp. 128-134, 2009.

[39] T. R. van Andel, B. Myren, and S. J.van Onselen, “Ghana’s herbal market,” Journal of Ethnopharmacology, vol. 140, no. 2, pp. 368378, 2012.

[40] V. L. Williams, E. T. F. Witkowski, and K. Balkwill, "Application of diversity indices to appraise plant availability in the traditional medicinal markets of Johannesburg, South Africa," Biodiversity and Conservation, vol. 14, no. 12, pp. 2971-3001, 2005.

[41] J. D. Olowokudejo, A. B. Kadiri, and V. A. Travih, "An ethnobotanical survey of herbal markets and medicinal plants in Lagos State of Nigeria," Ethnobotanical Leaflets, vol. 12, pp. 851-865, 2008.

[42] C. S. Olsen and H. O. Larsen, "Alpine medicinal plant trade and Himalayan mountain livelihood strategies," Geographical Journal, vol. 169, no. 3, pp. 243-254, 2003.

[43] S. Lee, C. Xiao, and S. Pei, "Ethnobotanical survey of medicinal plants at periodic markets of Honghe Prefecture in Yunnan Province, SW China," Journal of Ethnopharmacology, vol. 117, no. 2, pp. 362-377, 2008.

[44] S. A. Mitchell, "The Jamaican root tonics: a botanical reference," Focus on Alternative and Complementary Therapies, vol. 16, no. 4, pp. 271-280, 2011.

[45] R. A. Bye and E. Linares, "The role of plants found in the Mexican markets and their importance in ethnobotanical studies," Journal of Ethnobiology, vol. 3, no. 1, pp. 1-13, 1983.

[46] E. Mati and H. De Boer, "Ethnobotany and trade of medicinal plants in the Qaysari Market, Kurdish Autonomous Region, Iraq," Journal of Ethnopharmacology, vol. 133, no. 2, pp. 490-510, 2011.

[47] I. Vandebroek, V. Reyes-García, U. P. de Albuquerque, R. W. Bussmann, and A. Pieroni, "Local knowledge: who cares?" Journal of Ethnobiology and Ethnomedicine, vol. 7, p. 35, 2011.

[48] D. R. A. Mans, J. R. Toelsie, Z. Jagernath et al., "Assessment of eight popularly used plant-derived preparations for their spasmolytic potential using the isolated guinea pig ileum," Pharmaceutical Biology, vol. 42, no. 6, pp. 422-429, 2004.

[49] S. Parveen, S. Das, C. Prakash Kundra, and B. M. J. Pereira, "A comprehensive evaluation of the reproductive toxicity of Quassia amara in male rats," Reproductive Toxicology, vol. 17, no. 1, pp. 45-50, 2003.

[50] L. S. Nelson, R. D. Shih, and M. J. Balick, Handbook of Poisonous and Injurious Plants, Springer, New York, NY, USA, 2006.

[51] I. Vandebroek and M. J. Balick, "Globalization and loss of plant knowledge: challenging the paradigm," PLoS ONE, vol. 7, no. 5, article e37643, 2012. 


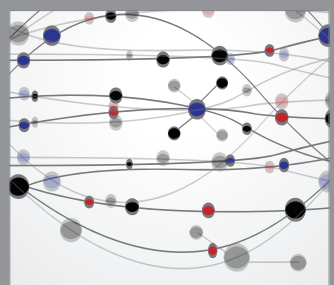

The Scientific World Journal
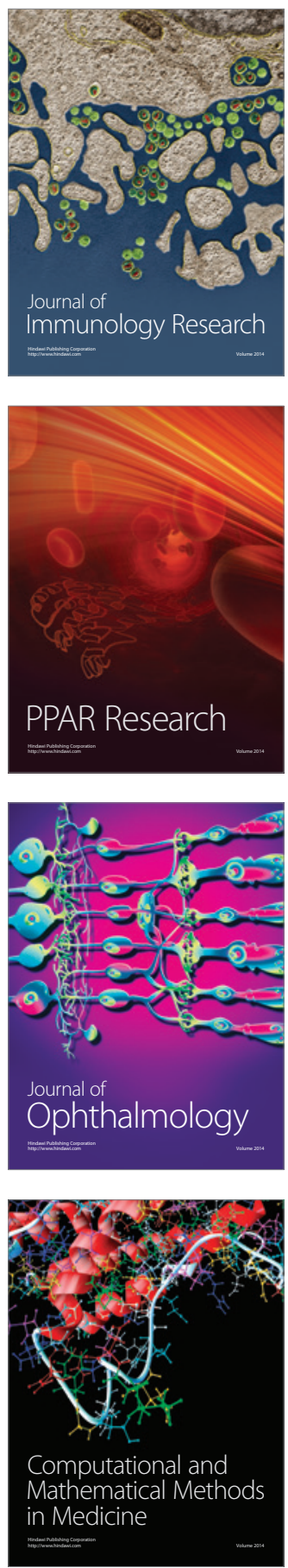

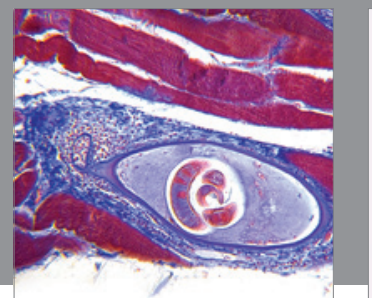

Gastroenterology

Research and Practice
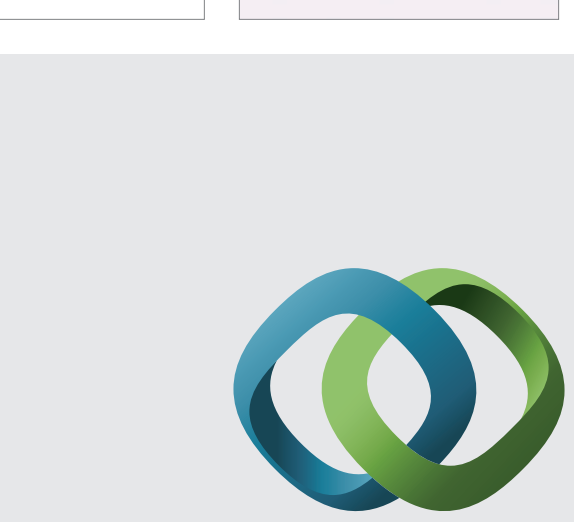

\section{Hindawi}

Submit your manuscripts at

http://www.hindawi.com
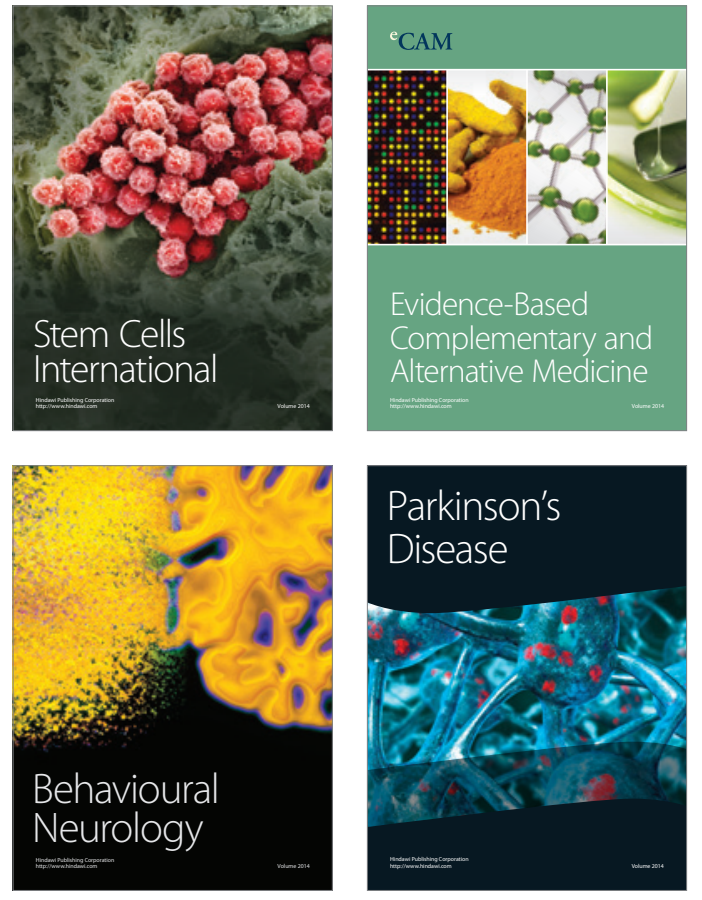
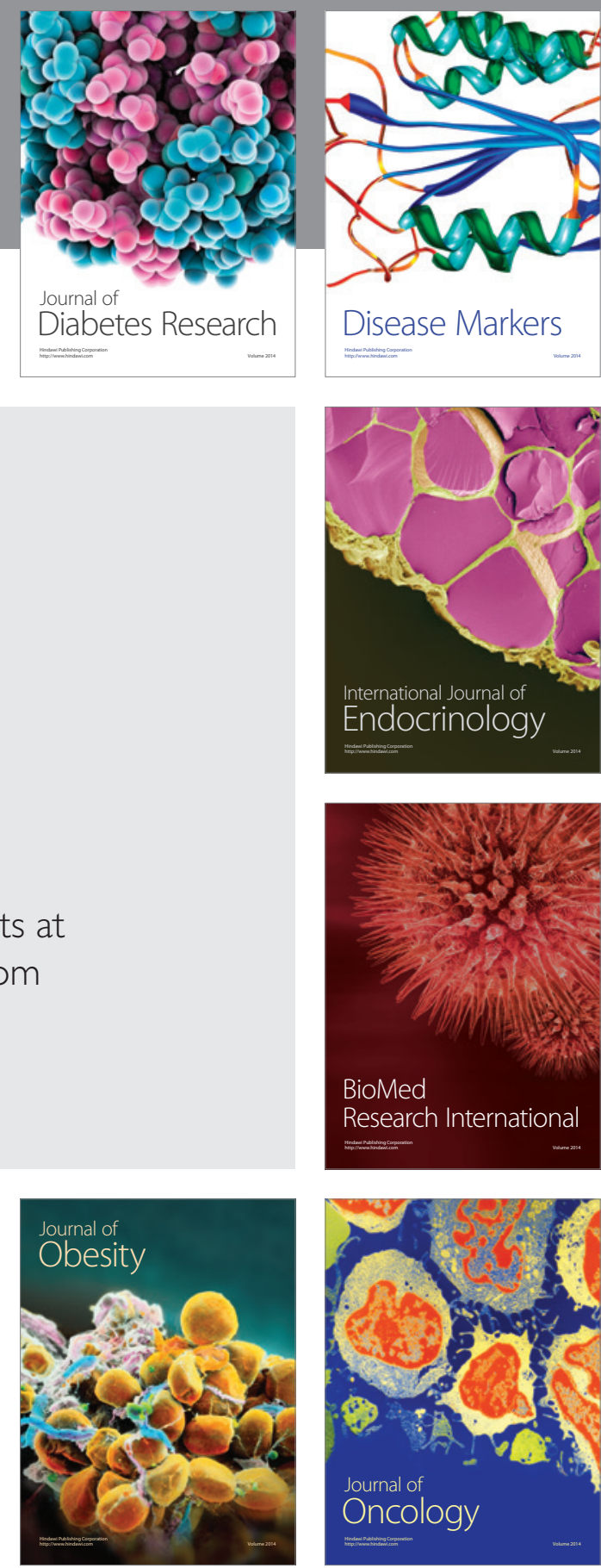

Disease Markers
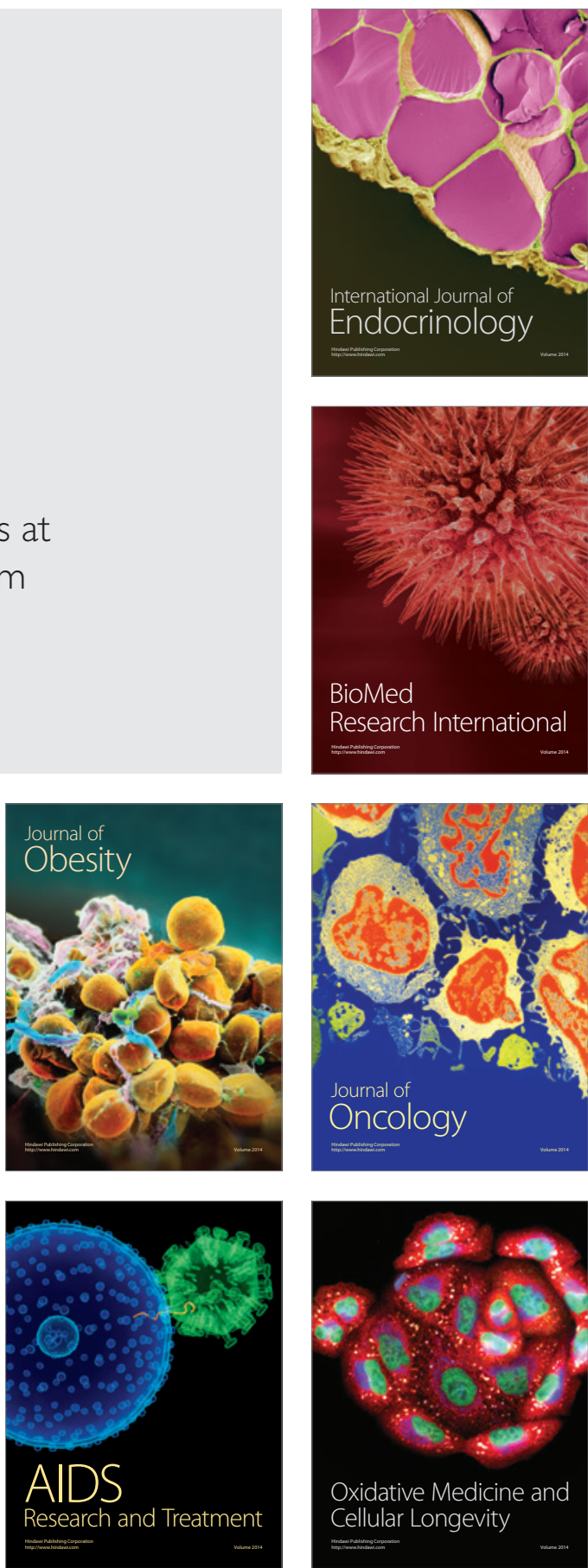